\title{
Potential nutritional and antioxidant activity of various solvent extracts from leaves and stem bark of Anisophyllea laurina R. Br ex Sabine used in folk medicine
}

\author{
Gbago Onivogui ${ }^{1,3}$, Xiaodan Zhang4, Mohamed Diaby², Clotaire Gna Maomy ${ }^{2}$, Yuanda Song ${ }^{1,2, *}$
}

${ }^{1}$ Center of Excellence for Functional Food and Health, School of Food Science and Technology, Jiangnan University, China , ${ }^{2}$ State Key Laboratory of Food Science and Technology, Jiangnan University, China, ${ }^{3}$ Center of Scientific research Rogbane Conakry, Guinea, ${ }^{4}$ College of Life Sciences, Zhejiang Sci-Tech University, Hangzhou, China

\begin{abstract}
Anisophyllea laurina is a plant that has been used in folk medicine to treat malaria, dysentery, diabetes, toothache and various skin diseases. Leaves extract had protein content of $9.68 \%$ and a high calcium content of $25084.317 \mathrm{mg} / 100 \mathrm{~g}$ while stem bark extract was found to contain greater amounts of calcium $(8560.96 \mathrm{mg} / 100 \mathrm{~g})$, potassium $(7649.47 \mathrm{mg} / 100 \mathrm{~g})$, magnesium $(1462.49 \mathrm{mg} / 100 \mathrm{~g})$ and iron $(973.33 \mathrm{mg} / 100 \mathrm{~g})$. Palmitic acid, linolenic acid, linoleic acid and oleic acid were the most abundant fatty acids in leaves and stem bark extracts. Furthermore, total phenolic (2382.39 mg GAE / $100 \mathrm{~g})$ and total flavonoid (385.79 mg QE/100 g) contents were abundant in stem bark while leaves extract was rich in total tannin content ( $3466.63 \mathrm{mg} \mathrm{CE} / 100 \mathrm{~g})$. However, both leaves and stem bark contained great amounts of vitamins and amino acids were a good source of antioxidant activities. For the individual polyphenol, stenophyllanin A (45.87 mg/g), casuarinin $(24.55 \mathrm{mg} / \mathrm{g})$ and digalloyl-HHDP-glucopyranose isomer $(15.63 \mathrm{mg} / \mathrm{g})$ were found to be the major compounds from the leaves whereas procyanidin tetramer $(14.89 \mathrm{mg} / \mathrm{g},(-)$-Epicatechin $(12.18 \mathrm{mg} / \mathrm{g})$ and procyanidin trimer $(11.25 \mathrm{mg} / \mathrm{g})$ were the most predominant compounds from the stem bark. Additionally, the results revealed a significant and strong correlation between phenolic compounds and antioxidant activities.
\end{abstract}

Uniterms: Anisophyllea laurina/extract/antioxidant activity. Anisophyllea laurina/extract/total phenolic. Proximate composition. Flavonoid. Tannin.

\section{INTRODUCTION}

Anisophyllea laurina $\mathbf{R}$. Br. ex Sabine comprise 25-36 species from the family Rhizophoraceae (Anisophylleaceae) are placed in four genera with disjunctive geographic distributions. A. laurina is the commonest mangrove and consequently accounts for a considerable area, distributed widely in West Africa (Guinea-Bissau to Sierra Leone), South East Asia, South America and West Malaysia (Sumatra, Peninsular Malaysia and Borneo) (Juncosa, 1988; Zhang, Simmons, Renner, 2007).

Furthermore, Neuwinger (Neuwinger, 2000) reported that $A$. laurina leaves are rich in tannins, a

\footnotetext{
*Correspondence: Y. Song. Center of Excellence for Functional Food and Health. School of Food Science \& Technology. Jiangnan University, No. 1800 Lihu Road, Wuxi, 214122 Jiangsu, China. E-mail: ysong@jiangnan.edu.cn; onivoguigbago@gmail.com
}

decoction of the leaves is used as a mouth rinse for toothache and the ground leaves are said to have medicinal properties to treat diabetes, emetics and to remove cataracts from the eyes, while the stem bark is used as remedy for dysentery (Lebbie, Raymond, 1995). Both leaves and stem bark were identified and are well-known as traditional medicine for treating malaria in Guinea (Balde et al., 2015). Ethanol and methanol extracts of the leaves and stem bark have shown potential as antibacterial and antifungal agent (Onivogui et al., 2015). In another study conducted by Kargbo, Onivogui and Song (2015) it was reported that the ethanol crude extract from leaves and stem bark of $A$. laurina exerted an inhibitory effect on $\alpha$-glycosidase and $\alpha$-amylase.

In recent years, basic research and observational studies have suggested that adequate intake of antioxidant vitamins or minerals may protect against the development of type 2 diabetes via reduction of oxidative stress and its 
associated metabolic abnormalities, including systemic inflammation, endothelial dysfunction, hypertension, and dyslipidemia (Song et al., 2010). The aim of this study was to evaluate the proximate profiles, total phenolic, flavonoids contents and antioxidant activity of leaves and stem bark of A. laurina.

\section{MATERIAL AND METHODS}

\section{Collection of plant materials}

Fresh mature whole leaves and stem bark of $A$. laurina R. Brex Sabine were collected in Coyah of Kindia region in September 2014 and identified by Traore Mohamed Sahar of the Research and Valorization Center on Medicinal Plants, Dubréka, Guinea. A voucher specimen of the plant was deposited with the number $5 \mathrm{HK} 4$ at the herbarium of the center.

\section{Proximate analysis of samples}

Crude protein content was determined using the Kjeldahl method with a conversion factor of 6.25. Lipid content was analyzed gravimetrically following Soxhlet extraction. Crude fiber was estimated by acid/alkaline hydrolysis of insoluble residues. Crude ash content was estimated by incineration in a muffle furnace at $550{ }^{\circ} \mathrm{C}$. The moisture content was determined gravimetrically. Carbohydrate contents were determined by difference [100-(protein + crude fat + ash + crude fiber $)$. All methodologies followed the recommendations according to the acid hydrolysis method (AOAC, 2000). Triplicate samples were analyzed for each sample.

\section{Mineral analysis}

The minerals ( $\mathrm{Zn}, \mathrm{Fe}, \mathrm{Cu}, \mathrm{Mn}, \mathrm{Na}, \mathrm{K}, \mathrm{Mg}$, and $\mathrm{Ca}$ ) were analyzed separately, using an Atomic absorption spectrophotometer (SpectraAA 220, USA Varian). The data reported represent the mean of three determinations. The minerals were expressed as $\mathrm{mg} / 100 \mathrm{~g}$ of dry Weight (DW).

\section{Vitamins}

Vitamins were analyzed using the method described by Erbaş, Certel and Uslu (2005). Peaks were verified by adding the standard vitamins to samples and individual peak area was calculated according to the peak area of corresponding standard vitamins. Results were calculated on a dry weight basis.

\section{Amino acid analysis}

Amino acid contents were analyzed using the method described by Jarrett et al. (1986). The amino acid composition was expressed as $\mathrm{g}$ of amino acid per $100 \mathrm{~g}$ of protein.

\section{Organic acids}

Organic acids were determined according to the method described by Usenik, Fabcic and Stampar (2008). The concentrations were expressed as mg per kg dry weight.

\section{Anti-nutritional factors analysis}

Total oxalate was determined as described by Day and Underwood (1986). The oxalate content was then calculated by taking $1 \mathrm{~mL}$ of $0.05 \mathrm{~mol} / \mathrm{L}$ of $\mathrm{KMnO}_{4}$ as equivalent to $2.2 \mathrm{mg}$ oxalate (Edwige, 2012). Phytate was determined using the method of Edwige, (Edwige 2012). The following equation gives the percentage of phytic acid:

$$
\text { Phytic acid }=\frac{0.66(10-V)}{m}
$$

where, $\mathrm{V}$ is the volume of iron (III) chloride solution in milliliters and $\mathrm{m}$ the sample mass in grams.

\section{Fatty acid analysis}

Preparation of fatty acid methyl esters (FAME) of both leaves and stem bark was determined according to the method described in AOAC (2000).

\section{Quantification of phenolic compound}

The total phenolic content (TPC) was determined using the Folin-Ciocalteu reagent as described by Gouveia and Castilho (2011). TPC was expressed as mg of gallic acid equivalents per 100 gram of dry weight (mg GAE/ $100 \mathrm{~g} \mathrm{DW}$ ) through a calibration curve of $0-400 \mu \mathrm{g} / \mathrm{mL}$ range. Total flavonoid content (TFC) was also measured as described by Gouveia and Castilho (2011). TFC was expressed as mg of quercetin equivalent per $100 \mathrm{~g}$ of dry weight (mg QE/100 g DW), through a calibration curve of quercetin of $0-400 \mu \mathrm{g} / \mathrm{mL}$. The total tannin content (TTC) was determined using the vanillin-methanol solution as described by Sun, Silva and Spranger (1998). TTC was expressed as $\mathrm{mg}(+)$-catechin equivalents per $100 \mathrm{~g}$ of dry weight (mg CE/100 g DW) through a calibration curve of $0-400 \mu \mathrm{g} / \mathrm{mL}$. 


\section{Phenolic profile analysis by UPLC LC-ESI-MS}

The mass spectra were recorded using the Waters ACQUITY UPLC ${ }^{\circledR}$ SYNAPTTM High Definition Mass Spectrometer systems (Waters, Milford, USA) equipped with an electrospray ion source and hybrid quadrupoletime-of-flight (Q-TOF) mass spectrometer with the MSE model. The Q-TOF instrument was operated in V mode for MS experiments with the TOF data collected between $\mathrm{m} / \mathrm{z}$ 100 and 1800 . The optimized condition was desolvation gas at $500 \mathrm{~L} / \mathrm{h}$ at a temperature of $400{ }^{\circ} \mathrm{C}$, cone gas at 50 $\mathrm{L} / \mathrm{h}$ and source temperature at $100^{\circ} \mathrm{C}$, capillary and cone voltages at $3 \mathrm{kV}$ and $30 \mathrm{v}$, respectively.

UPLC data were produced using the Waters ACQUITY UPLC systems (WATERS MALDI SYNAPT Q-TOF MS, Milford, USA) equipped with a binary pump, an autosampler, a degasser, and a diode-array detector (DAD). The system was controlled with MassLynx V4.1 software. The DAD was monitored in the range 200-600 $\mathrm{nm}$. The chromatographic column UPLC ${ }^{\mathrm{TM}}$ BEH AMIDE $\mathrm{C} 18(2.1 \mathrm{~mm} \times 100 \mathrm{~mm}, 1.7 \mu \mathrm{m})$ was used and eluted with a linear gradient of A: $100 \%$ acetonitrile and B: $0.1 \%$ formic acid at a flow rate of $0.3 \mathrm{~mL} / \mathrm{min}$ : $0-5 \%$ A, $0-17 \mathrm{~min} ; 5-60 \%$ A, 17-20 min; 60-100\% A, 20-22 min; 100-5\% A 22-22.1 $\min ; 5 \% \mathrm{~A}, 22.1-25 \mathrm{~min}$. The temperature was ratting at $45^{\circ} \mathrm{C}$. The injection volume was $0.5 \mu \mathrm{L}$. The accurate mass and composition for the precursor and fragment ions were calculated using the MassLynx 4.1 software. For the quantitative analysis of phenolic compounds, the standard curve of catechin, (-)-epicatechin 3-O-gallate and isorhamnetin-3-O-glucoside $(2-200 \mu \mathrm{g} / \mathrm{mL})$ were used to quantify the phenolic compounds. The analytical curve was linear $\left(\mathrm{r}^{2}=0.99\right)$; the limit of detection was $0.2 \mu \mathrm{g} / \mathrm{mL}$, and the limit of quantification was $0.5 \mu \mathrm{g} / \mathrm{mL}$ as calculated using the parameters of the analytical curves (standard deviation and the slope). The results were expressed in mg per $g$ of sample. Compounds concentrations were calculated in triplicate and the mean value.

\section{Determination of antioxidant activities}

DPPH radical scavenging activity assay followed a reported method by Gouveia and Castilho (2011). The DPPH radical scavenging effect of the sample was expressed based on the Trolox calibration curve, as $\mu \mathrm{mol}$ Trolox equivalent per $100 \mathrm{~g}$ of dried fruit weight ( $\mu \mathrm{mol}$ eq. Trolox/100 g). Ferric reducing antioxidant power (FRAP) assay was conducted according to Lu et al. (2011). A standard curve was made with Trolox, and the results were expressed as $\mu \mathrm{mol}$ Trolox equivalents (TE) per one gram dry weight (DW) of the fruit powders. The ABTS radical scavenging activity assay was performed according to the procedures of Gouveia and Castilho (2011). Results were expressed as $\mu \mathrm{mol}$ Trolox equivalent (TE)/100 $\mathrm{g}$ of extract.

\section{RESULTS AND DISCUSSION}

The proximate composition and mineral content of leaves and stem bark extracts of A. laurina is shown in table I for comparison. The crude protein content of leaves $(9.68 \pm 0.9 \%)$ was high when compared with stem bark, while stem bark extract was found to contain substantially greater amounts of ash $(11.93 \%)$. The carbohydrate and Food energy (g/calories) amounts were found to be similar in both leaves and stem bark extracts (Table I). In this work, it was observed that leaves and stem bark contained appreciable quantities of several essential mineral macronutrients necessary for human health maintenance. The stem bark appeared to be an important source of mineral elements, such as calcium (8560.96 $\mathrm{mg} / 100 \mathrm{~g})$, potassium $(7649.47 \mathrm{mg} / 100 \mathrm{~g})$, magnesium $(1462.49 \mathrm{mg} / 100 \mathrm{~g})$, iron $(973.33 \mathrm{mg} / 100 \mathrm{~g})$, sodium $(242.38 \mathrm{mg} / 100 \mathrm{~g})$ and zinc $(15.91 \mathrm{mg} / 100 \mathrm{~g})$, while the leaves extract was especially high in calcium (25084.32 $\mathrm{mg} / 100 \mathrm{~g}$ ) followed by potassium $(3583.47 \mathrm{mg} / 100 \mathrm{~g})$, magnesium (495.36 mg/100 g) and iron $(180.86 \mathrm{mg} / 100$ $\mathrm{g})$. The high levels of $\mathrm{Ca}, \mathrm{Mg}$ and $\mathrm{K}$ are collectively known to reduce hypertension and blood pressure as well as used in the prevention and treatment of high blood pressure. The leaves and stem bark of $A$. laurina had high amounts of macro and micro-nutrients especially $\mathrm{Ca}, \mathrm{K}, \mathrm{Mg}$ and $\mathrm{Fe}$ when compared with other green leafy vegetables (Abbas et al., 2015; Mendez et al., 2014).

Regarding fatty acids (FA) composition of leaves and stem bark as recorded in Table II, the major fatty acids found in stem bark extracts samples were palmitic acid followed by linoleic acid and oleic acid. For leaves extract linolenic acid, was the most abundant fatty acid, and was followed by palmitic acid, linoleic acid and palmitoleic acid. Furthermore, total polyunsaturated fatty acids (TPUFA) in leaves at $58.40 \%$ predominated over total saturated fatty acids (TSFA) and monounsaturated fatty acids (MUFA) at $41.60 \%$. TPUFA content $(50.39 \%)$ in stem bark was similar to that of TSFA at $49.60 \%$. Linolenic acid has excellent anti-inflammatory effects since it is transformed by 15-lipoxygenase into an effective metabolite with same pathway as linoleic acid. It also has excellent inhibitory effects against inflammations from burns and erythema (Anitha, 2012). The high content of linolenic acid, oleic acid and linolenic acid in leaves may be beneficial to human health. However, many scientists have reported that saturated fatty acids may impact blood 
TABLE I - Proximate composition and mineral contents of leaves and stem bark

\begin{tabular}{lcc}
\hline Constituents & Stem bark & Leaves \\
\hline Moisture (\%) & $87.91 \pm 0.10$ & $88.22 \pm 0.07$ \\
Crude Protein (N x 6.25\%= & $3.84 \pm 0.04$ & $9.6792 \pm 0.05$ \\
Crude Fiber (\%) & $3.56 \pm 0.05$ & $5.23 \pm 0.03$ \\
Fats/oil (\%) & $2.26 \pm 0.01$ & $1.6 \pm 0.8$ \\
Ash (\%) & $11.93 \pm 0.02$ & $7.96 \pm 0.03$ \\
Carbohydrates (\%) & $78.41 \pm 0.08$ & $75.5308 \pm 0.07$ \\
Food energy (g/calories) & $349.34 \pm 0.12$ & $355.24 \pm 0.19$ \\
\hline Mineral content (mg/100 g) & & \\
\hline Zinc (Zn) & $15.914 \pm 1.56$ & $44.899 \pm 0.67$ \\
Iron (Fe) & $973.329 \pm 1.90$ & $180.86 \pm 0.37$ \\
Manganese (Mn) & $61.225 \pm 0.24$ & $41.13 \pm 0.65$ \\
Copper (Cu) & $5.920 \pm 0.58$ & $1.096 \pm 0.45$ \\
Potassium (K) & $7649.47 \pm 5.3$ & $3583.473 \pm 2.05$ \\
Sodium (Na) & $242.38 \pm 1.76$ & $29.81 \pm 0.78$ \\
Magnesium (Mg) & $1462.485 \pm 0.7$ & $495.36 \pm 0.9$ \\
Calcium (Ca) & $8560.96 \pm 3.05$ & $25084.317 \pm 4.10$ \\
\hline Valus
\end{tabular}

Values are means \pm standard deviation of three determinations $(\mathrm{n}=3)$.

TABLE II - Fatty acid content of leaves and stem bark of $A$. laurina

\begin{tabular}{lccc}
\hline Retention time & Fatty acids compound & Stem $\%$ & Leaves $\%$ \\
\hline 9.393 & Lauric acid methyl ester (C12:0) & $2.02 \pm 0.01$ & $0.55 \pm 0.02$ \\
12.003 & Myristic acid Methyl ester (C14:0) & $3.52 \pm 0.02$ & $1.43 \pm 0.05$ \\
14.905 & Palmitic acid (C16:0) & $36.49 \pm 0.58$ & $34.69 \pm 0.8$ \\
23.886 & Arachidic acid (C20:0) & $0.56 \pm 0.06$ & $0.33 \pm 0.07$ \\
18.859 & Stearic acid (C18:0) & $5.76 \pm 0.07$ & $4.37 \pm 0.01$ \\
29.689 & Behenic acid (C22:0) & $1.26 \pm 0.03$ & $0.23 \pm 0.01$ \\
\hline TPSFA & & $49.60 \pm 0.77$ & $41.60 \pm 0.96$ \\
\hline 15.327 & Palmitoleic acid (C16:1) & $1.25 \pm 0.01$ & $7.58 \pm 0.06$ \\
19.3 & Oleic acid (C18:1) & $16.52 \pm 0.15$ & $4.77 \pm 0.12$ \\
20.384 & Linoleic acid (C18:2) & $27.76 \pm 0.58$ & $8.6 \pm 0.28$ \\
21.999 & Linolenic acid (C18:3) & $4.86 \pm 0.10$ & $37.45 \pm 0.26$ \\
\hline TPUFA & & $50.39 \pm 1.17$ & $58.4 \pm 1.30$ \\
\hline
\end{tabular}

Values are means \pm standard deviation of three determinations $(n=3)$.

cholesterol levels by slowing down the mechanisms that removes circulating LDL from the blood. Palmitic, myristic and lauric acids increase blood cholesterol whereas oleic acid, stearic, linoleic acid and linolenic acid decrease total blood cholesterol content (Fattore et al., 2014).

The vitamin contents and anti-nutrients composition of the leaves and stem bark are presented in Table III.
Vitamin C (316.79 mg/100 g) was the most abundant in the leaves extract followed by nicotinamin $(208.33 \mathrm{mg} /$ $100 \mathrm{~g})$, thiamin $(141.67 \mathrm{mg} / 100 \mathrm{~g})$ and pyridoxine $(108.33 \mathrm{mg} /$ $100 \mathrm{~g})$. In stem bark extract, pyridoxine $(108.33 \mathrm{mg} / 100 \mathrm{~g})$ and nicotinamin $(208.33 \mathrm{mg} / 100 \mathrm{~g})$ were the main vitamins detected whilst vitamin $C$ was not detected. This study suggests that leaves are a rich source of vitamin $\mathrm{C}$ and calcium that may be developed as a functional ingredient 
in nutraceuticals, and health-promoting phytochemicals. Multivitamins and calcium are the most commonly used dietary supplements in the U.S and are advocated for as an attractive option for preventing chronic diseases, such as cancer, cardiovascular disease and type 2 diabetes (Song et al., 2010)

The results for the anti-nutrients composition showed that leaves and stem bark have similar values of oxalates and phytic acid. The phytic acid $(907.53 \mathrm{mg} / 100$ g) and oxalate $(27.57 \mathrm{mg} / 100 \mathrm{~g})$ contents of the leaves did not show any significant difference compared with those of the stem bark. For organic acids the leaves extracts were mainly high in malic acid $(6105.66 \mathrm{mg} / 100 \mathrm{~g})$, followed by citric $(64.56 \mathrm{mg} / 100 \mathrm{~g})$ and tartaric acids $(13.06 \mathrm{mg} / 100$ g) (Table III). The high amount of malic acid found in leaves extracts probably contributed to its antimicrobial activity as reported by Onivogui et al. (2015). On the other hand, stem bark extracts showed moderate amounts of organic acids such as citric acid $(60.82 \mathrm{mg} / 100 \mathrm{~g})$, acetic acid (34.29 mg/100 g) and malic acid (19.82 mg/100 g). The organic acids contribute towards increased shelf life, stability and microbiological safety of the food (Chen et al., 2014).

Regarding the amino acid profiles in Table IV, the isoleucine, lysine, threonine and alanine contents of leaves and stem bark were not significantly different ( $\mathrm{P}$ value $>0.05$ ), whereas they were significantly different for other remaining amino acids. However, leaves extracts were a good source of principal amino acid as valine, leucine, phenylalanine, arginine and glutamic acid. On the other hand, the non-essential amino acids as aspartic acid, histidine, cysteine, serine, glycine, tyrosine and proline in stem bark were higher than in leaves. The essential amino acids observed in both leaves and stem bark were higher than the suggested amino acids requirements. Therefore leaves and stem bark of $A$. laurina are considered nutritious because their essential amino acid profiles are higher than the reference levels required for children as their bodies are unable to synthesize them (WHO, 2007).

\section{Antioxidant compounds}

Results for the antioxidant compounds of leaves and stem bark of A. laurina from different extracting solvents are presented in Table V. The total phenolic contents showed great variations in leaves and stem bark extracts, and the range were from 1245.47 to 2294.43 $\mathrm{mg} \mathrm{GA} / 100 \mathrm{~g}$ and 1506.41 to $2382.39 \mathrm{mg} \mathrm{GAE} / 100$ $\mathrm{g}$, respectively. The results showed that the maximum amounts of TPC in the stem bark (2382.39 mg GAE/100 g) was slightly higher than that from leaves $(2194.43 \mathrm{mg}$ $\mathrm{GAE} / 100 \mathrm{~g}$ ). The values for the total phenolic contents obtained in this study were found to be lower than those from leaves and stem bark extracts of $T$. Indica as reported by Razali et al. (2012). Regarding total flavonoids content, the results also showed great variation in different extracts, and the ranges were from 104.41 to $346.14 \mathrm{mg} \mathrm{QE} / 100 \mathrm{~g}$ in leaves and 292.98 to $385.79 \mathrm{mg}$

TABLE III - Vitamins, organic acid and anti-nutritional content of leaves and stem bark

\begin{tabular}{lcc}
\hline Constituents & Stem $\mathbf{~ g / 1 0 0 ~ g ~}$ & Leaves $\mathbf{~ g / 1 0 0 ~ g ~}$ \\
\hline Ascorbic acid (C) & $0.9 \pm 0.05$ & $316.79 \pm 0.8$ \\
Thiamin (B1) & $50 \pm 0.01$ & $141.667 \pm 0.15$ \\
Riboflamin(B2) & $58.33 \pm 0.02$ & $26.667 \pm 0.03$ \\
Pyridoxine(B6) & $300 \pm 0.06$ & $108.33 \pm 0.33$ \\
Nicotinamin (PP) & $133.33 \pm 0.21$ & $208.33 \pm 0.15$ \\
Cyanocobalamin & $1.75 \pm 0.08$ & $3.5 \pm 0.01$ \\
Malic acid & $19.82 \pm 0.02$ & $6105.66 \pm 0.15$ \\
Citric acid & $60.82 \pm 0.34$ & $64.56 \pm 0.21$ \\
Tartaric acid & $5.8628 \pm 2.5$ & $13.06 \pm 1.5$ \\
Fumaric acid & $0.216 \pm 0.05$ & $0.31 \pm 0.08$ \\
Lactic acid & $4.70 \pm 0.15$ & $5.6 \pm 0.02$ \\
Acetic acid & $34.29 \pm 0.03$ & $6.5 \pm 0.07$ \\
Phytate & $895.576 \pm 0.45$ & $907.53 \pm 0.58$ \\
Oxalate & $543.54 \pm 0.03$ & $275.656 \pm 0.01$ \\
\hline
\end{tabular}

Values are means \pm standard deviation of three determinations $(n=3)$. 
TABLE IV - Amino acid composition from leaves and stem bark extracts of $A$. laurina as compared to the FAO/WHO/UNU reference pattern ( $\mathrm{mg} / \mathrm{g}$ protein)

\begin{tabular}{|c|c|c|c|}
\hline Constituents & Stem bark mg/g & Leaves $\mathrm{mg} / \mathrm{g}$ & FAO/WHO reference protein \\
\hline Leucine & $82.39 \pm 0.45$ & $97.49 \pm 0.52$ & 20 \\
\hline Isoleucine & $60.45 \pm 0.52$ & $60.68 \pm 0.33$ & 25 \\
\hline Lysine & $76.14 \pm 0.33$ & $71.00 \pm 0.58$ & 30 \\
\hline Phenylalanine & $60.20 \pm 0.52$ & $75.50 \pm 0.45$ & 25 \\
\hline Threonine & $43.16 \pm 0.23$ & $43.56 \pm 0.33$ & 15 \\
\hline Methionine & $4.13 \pm 0.07$ & $7.46 \pm 0.03$ & 15 \\
\hline Valine & $7.48 \pm 0.06$ & $70.70 \pm 0.82$ & 26 \\
\hline \multicolumn{4}{|l|}{ Non-essential } \\
\hline Arginine & $50.79 \pm 0.78$ & $60.47 \pm 0.15$ & \\
\hline Histidine & $64.14 \pm 0.34$ & $30.34 \pm 0.45$ & \\
\hline Cysteine & $11.54 \pm 0.54$ & $1.39 \pm 0.01$ & \\
\hline Aspartic acid & $106.63 \pm 0.76$ & $93.79 \pm 0.23$ & \\
\hline Glutamic acid & $109.79 \pm 0.52$ & $124.70 \pm 0.58$ & \\
\hline Serine & $41.86 \pm 0.15$ & $36.98 \pm 0.21$ & \\
\hline Glycine & $76.86 \pm 0.07$ & $60.77 \pm 0.33$ & \\
\hline Alanine & $64.26 \pm 0.21$ & $64.12 \pm 0.15$ & \\
\hline Tyrosine & $53.17 \pm 0.08$ & $41.52 \pm 0.03$ & 39 \\
\hline Proline & $87.00 \pm 0.45$ & $59.54 \pm 0.05$ & \\
\hline
\end{tabular}

Values (Mean $\pm \mathrm{SD}$ ) in the same column with different letters are significantly at $(\mathrm{P}<0.05), \mathrm{n}=3$.

QE/100 g in stem bark. TFC of leaves of A. laurina was lower compared to that from T. montanum leaves 58.48 mg RU/g (Stankovic et al., 2011). Furthermore, the TMAC ranged widely from 8.56 to $30.75 \mathrm{mg} \mathrm{C} 3 \mathrm{G} / 100 \mathrm{~g}$ for leaves and 2.35 to $60.65 \mathrm{mg} \mathrm{C} 3 \mathrm{G} / 100 \mathrm{~g}$ for stem bark. On the other hand, total tannins content of stem bark and leaves extracts in the various solvents ranged from 123.73 to $2391.94 \mathrm{mg} \mathrm{CE} / 100 \mathrm{~g}$ and 1322.41 to 3466.63 $\mathrm{mg} \mathrm{CE} / 100 \mathrm{~g}$, respectively. The total tannin contents (TTC) of the leaves extracts were higher than those from stem bark and this could probably be due to high diversity of hydrolysable tannins found in leaves by UPLC-QTOF-MS analysis. The total tannin contents (TTC) of leaves and stem bark in various extracting solvents was significantly higher than those from leaves of Aegle marmelos (12.377 mg/g) (Parvathi, Ramya, Rekha, 2013). With respect to the extraction solvent used in this study, the results showed that antioxidant composition in the leaves and stem bark were significantly different $(p<0.05)$. It was further observed that in all the plant parts used, the highest levels of antioxidant composition were found in the ethanol extract followed by methanol, ethyl acetate and water and this might be attributed to their polarity and good solubility for TPC (Korekar et al., 2011).

\section{Antioxidant activities}

Results of the different antioxidant activities for different plant parts of A. laurina as determined by ABTS, DPPH and FRAP assay using the different extraction solvents are shown in Figure 1. Results showed that ethanol extracts of A. laurina have the highest levels of DPPH. As shown in Figure 1(a), the highest DPPH value was obtained from leaves extract as $76333.5 \mu \mathrm{mol}$ $\mathrm{TE} / 100 \mathrm{~g}$, followed by stem bark extract with 65262.3 $\mu \mathrm{mol} \mathrm{TE} / 100 \mathrm{~g}$. These results suggest that ethanol was found to be the most efficient solvent to extract DPPH from different parts of $A$. laurina. In this study, the results of FRAP showed good variation and strong antioxidant activity in different extracts, and the ranges were from 19146.6 to $32375.2 \mu \mathrm{mol} \mathrm{TE} / 100 \mathrm{~g}$ in leaves and 10146.6 to $36060.9 \mu \mathrm{mol} \mathrm{TE} / 100 \mathrm{~g}$ in stem bark (Figure 1(b)). The highest levels of activities evaluated by the FRAP assay were observed in ethanol extract of stem bark (36060.9 $\mu \mathrm{mol} \mathrm{TE} / 100 \mathrm{~g}$ ). These results are in agreement with that of a previous report by Korekar et al. (2011) who found the antioxidant activity of Seabuckthorn (Hippophae rhamnoides $L$.) in the order of stem bark >leaves. The antioxidant activities of $A$. laurina leaves and stem bark extracts determined as ABTS ranged from 3203.45 to 
Potential nutritional and antioxidant activity of various solvent extracts from leaves and stem bark of Anisophyllea laurina $\mathrm{R}$. Br ex Sabine

TABLE V - Total phenolic, flavonoids, tannin contents and antioxidant activity of various solvent extracts from Anisophyllea laurina Leaves and stem bark

\begin{tabular}{cccccc}
\hline & solvent & $\begin{array}{c}\text { yield } \\
\mathbf{m g} / \mathbf{1 0 0} \mathbf{g}\end{array}$ & $\begin{array}{c}\text { TPC GAE } \\
\mathbf{m g} / \mathbf{1 0 0} \mathbf{g}\end{array}$ & $\begin{array}{c}\text { TFC QE } \\
\mathbf{~ m g / 1 0 0 ~ g}\end{array}$ & $\begin{array}{c}\text { CTC CE } \\
\mathbf{m g} / \mathbf{1 0 0} \mathbf{g}\end{array}$ \\
\hline \multirow{3}{*}{ Leaves extracts } & Ethanol & $39.34^{\mathrm{a}} \pm 0.01$ & $2294.43^{\mathrm{d}} \pm 0.04$ & $346.14^{\mathrm{b}} \pm 0.03$ & $3466.63^{\mathrm{d}} \pm 0.03$ \\
& Methanol & $48.18^{\mathrm{c}} \pm 0.02$ & $2155.91^{\mathrm{c}} \pm 0.01$ & $305.45^{\mathrm{b}} \pm 0.03$ & $2482.76^{\mathrm{b}} \pm 0.02$ \\
& Ethyl acetate & $33.96^{\mathrm{d}} \pm 0.04$ & $2098.06^{\mathrm{a}} \pm 0.04$ & $294.83^{\mathrm{a}} \pm 0.01$ & $1307.43^{\mathrm{a}} \pm 0.03$ \\
& Water & $26.36^{\mathrm{b}} \pm 0.15$ & $1245.47^{\mathrm{b}} \pm 0.01$ & $104.41^{\mathrm{a}} \pm 0.02$ & $1322.41^{\mathrm{c}} \pm 0.03$ \\
\hline \multirow{3}{*}{ Stem bark } & Ethanol & $22.40^{\mathrm{a}} \pm 0.02$ & $2382.39^{\mathrm{d}} \pm 0.05$ & $385.79^{\mathrm{c}} \pm 0.07$ & $2391.94^{\mathrm{d}} \pm 0.03$ \\
& Methanol & $34.30^{\mathrm{b}} \pm 0.10$ & $2222.42^{\mathrm{b}} \pm 0.02$ & $338.37^{\mathrm{b}} \pm 0.01$ & $2055.13^{\mathrm{a}} \pm 0.02$ \\
& Ethyl acetate & $27.84^{\mathrm{d}} \pm 0.70$ & $2191.08^{\mathrm{a}} \pm 0.01$ & $315.34^{\mathrm{a}} \pm 0.03$ & $212.57^{\mathrm{c}} \pm 0.05$ \\
& Water & $24.56^{\mathrm{c}} \pm 0.05$ & $1506.41^{\mathrm{c}} \pm 0.06$ & $292.98^{\mathrm{a}} \pm 0.03$ & $123.73^{\mathrm{b}} \pm 0.06$ \\
\hline
\end{tabular}

$\mathrm{Mean} \pm \mathrm{SD}$ of three replication; for each column, values followed by the different letters are significantly different at $\mathrm{P}<0.05$.

$21717.32 \mu \mathrm{mol} \mathrm{TE} / 100 \mathrm{~g}$ and 2263.12 to $26746.6 \mu \mathrm{mol}$ TE/100 g dry weight (DW), respectively. ABTS values of leaves and stem bark in various extracting solvents were in the following order: ethanol $>$ methanol $>$ ethyl acetate $>$ water. In comparison with other plant parts, $A$. laurina pulp extracts were found to be a good source of antioxidant by ABTS than the leaves and stem bark methanol extract of Tamarindus indica L as reported by Razali et al. (2012). The correlation tests in leaves showed a strong positive correlation between TPC, TFC, TTC and FRAP $(\mathrm{r}=0.952$, $\mathrm{p}<0.01)$, TPC, TFC, TTC and ABTS $(\mathrm{r}=0.998, \mathrm{p}<0.01)$, TPC, TFC, TTC and DPPH $(\mathrm{r}=0.982, \mathrm{p}<0.01)$ in both leaves and stem bark. These values are in line with the results reported by Hwang et al. (2014) in which high correlation coefficients were found between the in vitro antioxidant activities and antioxidant compounds of extracts from cultivated black chokeberry and blueberry.

\section{Phenolic profile by UPLC-ESI-MS}

A total of nineteen phenolic compounds were identified from methanol extracts of the leaves and stem bark of A. laurina as shown in Table VI and Figure 2. Identification of the MS chromatogram compounds of phenolic compounds by detached molecular weight was done based on the search for $[\mathrm{M}-\mathrm{H}]$ - ions, using extracted ion mass chromatograms together with the interpretation of their ESI/IT/MS fragments in comparison with those found in reported literature. These compounds were the most prominent compounds detected at $220-360 \mathrm{~nm}$ from the leaves and at $\lambda=223-280 \mathrm{~nm}$ from stem bark.

On the basis of the compounds area of each signal in mass chromatograms, Stenophyllanin A, Casuarinin (galloyl-bis-HHDP-glucose) were the most abundant
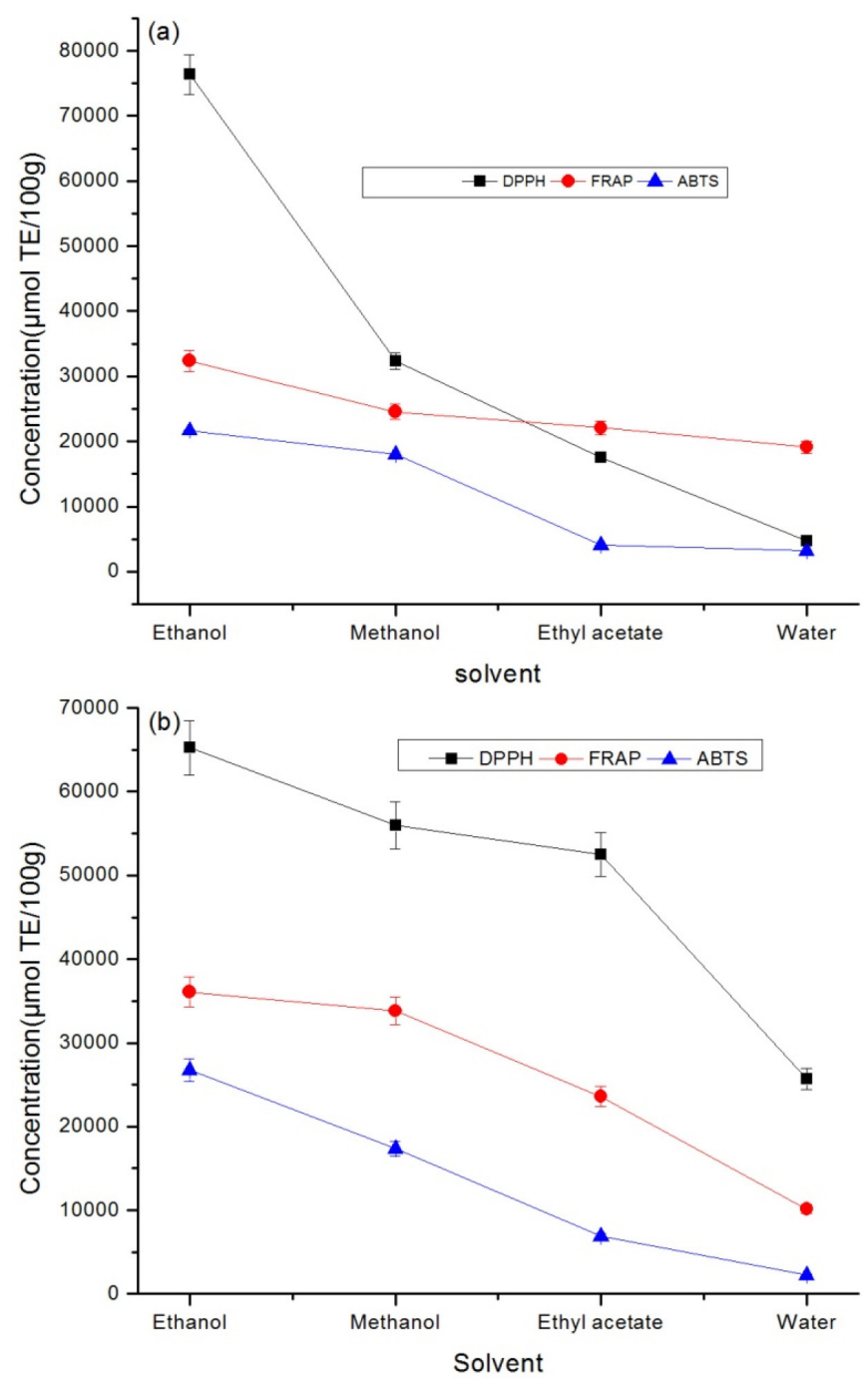

FIGURE 1 - DPPH, FRAP and ABTS from various solvent extracts of leaves (a) and stem bark (b) from Anisophyllea laurina R. Br. ex Sabine. 
compounds identified in leaves extract (Figure 2 A). On the other hand, Procyanidin tetramer, Procyanidin dimer $\mathrm{B} 1$ isomer were the major compounds identified in stem bark (Figure 2 B). The hydrolysable tannins as gallotannin and ellagitannin type were the most abundant compounds identified in leaves extract. Compound 1 was identified as digalloyl-HHDP-glucopyranose isomer with $[\mathrm{M}-\mathrm{H}]$ at $\mathrm{m} / \mathrm{z}$ 784.1. Its fragmentation pattern involved the loss of galloyl and HHDP moieties ( $\mathrm{m} / \mathrm{z} 633$ and 481$)$ respectively. The fragmentation patterns of the majority of this compound have been identified (Barros et al., 2013a). Compound 2 was identified as Pterocarinin A isomer [M-H] at m/z 1067.1, with the fragment at $\mathrm{m} / \mathrm{z}$ 933, 917, 783, 301, 275 by comparing the obtained $\mathrm{MS}^{2}$ fragmentation patterns with published data. Further, compound 3 was identified as stenophyllanin A/B isomer (galloyl-HHDP-glucose) (Figure 3(a)) with [M-H] at $\mathrm{m} / \mathrm{z}$ 1207.1. The fragment ions at m/z 917 ([M-H-289]', loss of Catechin), m/z 602 (deprotonated two ellagic acids), m/z 289 (deprotonated catechin), m/z 275 after loss of $\mathrm{CH}_{2}[\mathrm{M}-\mathrm{H}-14]$; gallic acid itself $[\mathrm{M}-\mathrm{H}]^{-}$at $\mathrm{m} / \mathrm{z} 169$ produced a fragment of $\mathrm{m} / \mathrm{z}$ 125) after the loss of $\mathrm{CO}_{2}$ whereas compound 4 was identified as casuarinin isomer (galloyl-bis-HHDPglucose) $[\mathrm{M}-\mathrm{H}]^{-} \mathrm{m} / \mathrm{z} 935.01$ (Figure 3 (b)). The fragment ions at $\mathrm{m} / \mathrm{z} 633,467,301,275,169$ and 125 were due to the loss of hexahydroxydiphenoyl moieties, galloyl-glucose moieties from the $[\mathrm{M}-\mathrm{H}]-$ and $[\mathrm{M}-\mathrm{H}-169]^{-}$ionsand $\mathrm{m} /$ z125 processed loss of $\mathrm{CO}_{2}$ group from the carboxylic acid moiety. These compounds have been identified in some plants by comparing the obtained $\mathrm{MS}^{2}$ profiles with those published (Barros et al., 2013b). On the other hand, compounds 5 and 8 were tentatively identified as procyanidin hexamer with $[2 \mathrm{M}-\mathrm{H}]^{2-}$ ion at $\mathrm{m} / \mathrm{z} 865.3$, corresponding to a monoisotopic mass of 1730.5 Daand EuprostinA isomer showing $[\mathrm{M}-2 \mathrm{H}]^{2-}$ ion at $\mathrm{m} / \mathrm{z} 618.98$ corresponding to a monoisotopic mass of $1236.97 \mathrm{Da}$ described in Cistus ladanifer by Barros et al. (2013a). The compound 7 with [M-H]- at $\mathrm{m} / \mathrm{z} 439.1$ with its fragment at $\mathrm{m} / \mathrm{z} 409$ ([M-H-30] $]^{-}$, loss of two hydrogen and $\left.\mathrm{CO}\right)$, $\mathrm{m} / \mathrm{z} 301$ ([M-H-138] $]^{-}$, loss of hexose), m/z 289 ([M-H$138]^{-}$, loss of hexose) was assigned to (-)-epicatechin 3-O-gallate (Figure 3(d)) whereas compound 8 with $[\mathrm{M}-\mathrm{H}]^{-}$ion at $\mathrm{m} / \mathrm{z} 557.02$ and $\mathrm{MS}^{2}$ fragmentation on negative mode gave [M-H-80]-ion at $\mathrm{m} / \mathrm{z} 477.05$ produced a fragment of $\mathrm{m} / \mathrm{z} 315$ after the loss of hexose, ([M-H$308]^{-}$, the loss of coumaroylhexose) ion at $\mathrm{m} / \mathrm{z} 301$ and 169 was tentatively identified as isorhamnetin-3-Oglucoside isomer. These two compounds were identified in both leaves and stem bark extracts of A. laurina. Some studies have focused on the ability of isorhamnetin to attenuate diabetes complications, such as diabetic cataract, lipid peroxidation and high blood glucose levels (Yokozawa et al., 2002).

For stem bark extract, the procyanidin trimer and hexamer were the most abundant phenolic compounds as shown in Table VI. The compound 1 at $\mathrm{t}_{\mathrm{R}}=8.182 \mathrm{mn}$ was identified as (Epi)afzelchine(epi)catechin isomer at $\mathrm{m} / \mathrm{z} 561$ with fragments ions m/z 407 ([M-H-154] $]^{-}$, loss of gallyol hexose), $\mathrm{m} / \mathrm{z} 289$ (deprotonated Catechin), itself [M-H] ${ }^{-}$at $\mathrm{m} / \mathrm{z} 289$ produced a fragment of $\mathrm{m} / \mathrm{z} 271$ ) after the loss of $\mathrm{H}_{2} \mathrm{O}$ which was identified in Quinchamalium chilensis by $\mathrm{S}$ Simirgiotis et al. (2012). On the basis of the mass spectra, three compounds 2, 3 and 5 were identified as procyanidin trimer and tetramer with $[2 \mathrm{M}-\mathrm{H}]^{-}$ion at $\mathrm{m} / \mathrm{z} 577.18$ corresponding to a monoisotopic mass of $1155.34 \mathrm{Da} . \mathrm{MS}^{2}$ fragmentation ions m/z 451 [M-H-126]', 425 [M-H-152] after the loss of galloyl group, 407 [M-H-170]- after the loss of gallic acid and $\mathrm{m} / \mathrm{z} 289$ (deprotonated catechin), whereas two procyanidins 4 and 7 were identified as procyanidin hexamer with $[2 \mathrm{M}-\mathrm{H}]^{2-}$ ion at $\mathrm{m} / \mathrm{z} 865.3$, corresponding to a monoisotopic mass of $1730.5 \mathrm{Da}$. The same type of compounds have been found and described in several plants (Dias et al., 2015). The compound 8 was identified as (-)-Epicatechin [M-H] at m/z 289.06 (Figure.3(c)), with fragments ions m/z 271 ([M-H-18]-, loss of $\left.\mathrm{H}_{2} \mathrm{O}\right), \mathrm{m} / \mathrm{z} 245$ ([M-H-44] $]^{-}$, loss of $\left.\mathrm{CO}_{2}\right), \mathrm{m} / \mathrm{z} 203$ ([M-H-86] $]^{-}$, loss of $\left.\mathrm{C}_{4} \mathrm{H}_{6} \mathrm{O}_{2}\right)$ and 164 ([M-H-125] $]^{-}$which has been previously described (Khallouki et al. 2007). Nevertheless, the compounds 6 and 9 were assigned as Procyanidin A dime $[\mathrm{M}-\mathrm{H}]^{-}$at $\mathrm{m} / \mathrm{z}[2 \mathrm{M}-\mathrm{H}]^{-} 647.2$ with monoisotopic mass of 1295.5 Da and Procyanidin tetramer [M- H] at m/z 849.3 respectively, as reported in the root bark of Anisophyllea dichostyla R. Br by Khallouki et al. (2007).

According the HPLC analysis of individual phenolic compounds, the standard curve of catechin, (-)-epicatechin 3-O-gallate and isorhamnetin-3-O-glucoside (2-200 $\mu \mathrm{g} /$ $\mathrm{mL}$ ) were used to quantify the phenolic compounds. The analytical curve was linear $\left(r^{2}=0.99\right)$; the limit of detection was $0.2 \mu \mathrm{g} / \mathrm{mL}$, and the limit of quantification was $0.5 \mu \mathrm{g} / \mathrm{mL}$ as calculated using the parameters of the analytical curves (standard deviation and the slope). A more detailed knowledge of the phenolic composition of the in leaves and stem bark was obtained with HPLC analysis, as we can see in Table 6. As previously observed in leaves, hydrolysable tannins including stenophyllanin A (45.87 mg/g), casuarinin (24.55 mg/g) and digalloylHHDP-glucopyranose isomer $(15.63 \mathrm{mg} / \mathrm{g}$ ) were found to be the major phenolic compounds in the leaves fractions. On the other hand, proanthocyanidins were the major phenolic compounds present in stem bark extracts. Among these compounds, procyanidin tetramer $(14.89 \mathrm{mg} / \mathrm{g}$, (-)-epicatechin $(12.18 \mathrm{mg} / \mathrm{g})$ and procyanidin trimer 
TABLE VI - Detected Compounds in methanol extract of A. laurina leaves and stem

\begin{tabular}{lccccc}
\hline No peak & $\mathbf{t}_{\mathbf{R}}$ & Compounds & MW & Fragment & mg/g \\
\hline 1 & \multicolumn{5}{c}{ Leaves extracts } \\
2 & 6.39 & HHDP di-galloyl hexoside & 784.1 & $301,275,169,163$ & 15.63 \\
3 & 8.2 & Pterocarinin A isomer & 1067.1 & $933,886,351,301,275,249,207$ & 10.71 \\
4 & 8.79 & Stenophyllanin A/B isomer & 1207 & $917,573,447,343,315,301,275,169$ & 45.87 \\
5 & 9.25 & Casuarinin/casuarictin isomer & 935 & $633,467,301,275,169,125$ & 24.55 \\
6 & 9.59 & Procyanidin dimer & 577.2 & $451,407,301,289,275,169$ & 4.07 \\
7 & 10.6 & Euprostin A isomer & 1238 & $935,917,785,633,301,275,169$ & 0.54 \\
8 & 14 & (-)-Epicatechin 3-O-gallate & 439 & $425,241,161$ & 1.49 \\
\hline & 14.61 & isorhamnetin-3-O-glucoside isomer & 557 & $477,315,300,241,181,153,139$ & 3.97 \\
\hline 1 & \multicolumn{5}{c}{ Stem bark extract } \\
2 & 8.18 & (Epi)afzelchine(epi)catechin isomer & 1447.5 & $723.2,561,543,407,381,329,289$ & 6.22 \\
3 & 9.33 & procyanidin trimer and tetramer & 1155.3 & $865.2,577.18,451,407,289.1$ & 1.11 \\
4 & 9.58 & procyanidin trimer and tetramer & 1155.3 & $865.2,577.18,451,407,289.1$ & 11.25 \\
5 & 9.85 & Procyanidin hexamer & 1730.5 & $865.3[2 \mathrm{M}-\mathrm{H}]-575.2,407,289,287.1,245$ & 2.09 \\
6 & 10.22 & procyanidin trimer and tetramer & 1155.3 & $865.2,577.18[2 \mathrm{M}-\mathrm{H}]-, 451,407,289.1$ & 4.87 \\
7 & 10.67 & Procyanidin dimer B1 isomer & 1295.5 & $647.2[2 \mathrm{M}-\mathrm{H}]-467,289.1,245,161$ & 7.74 \\
8 & 10.84 & Procyanidin hexamer & 1730.5 & $1137.4,919,865.3[2 \mathrm{M}-\mathrm{H}]-, 577.2,407,289$ & 6.92 \\
9 & 11.03 & (-)-Epicatechin & 289.1 & $271,245,203,137,125$ & 12.18 \\
10 & 11.48 & Procyanidin tetramer & 849.3 & $723,577.2,407,289,287,245,161,125$ & 14.89 \\
11 & 14.02 & (-)-Epicatechin 3- $O$-gallate & 439.1 & $425,241,161$ & 2.75 \\
\hline
\end{tabular}

$\mathrm{t}_{\mathrm{R}}=$ retention time, $\mathrm{MW}=$ molecular weight
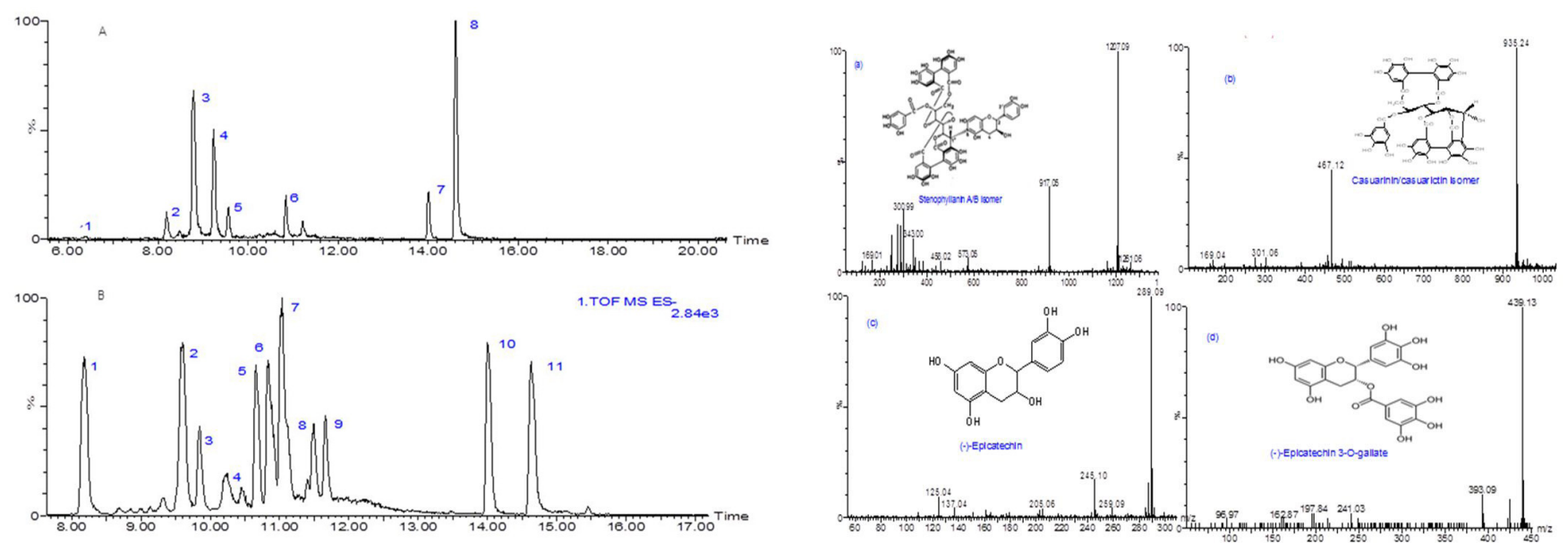

FIGURE 2 - UPLC-TOF-ESI-MS peak chromatograms of leaves (Figure 2A.) and stem bark (Figure 2B), MS in negative ion mode, $\mathrm{UV}$ at $280 \mathrm{~nm}$, for the methanol extract from Anisophyllea laurina.

$(11.25 \mathrm{mg} / \mathrm{g})$ were the most predominant compound in stem bark.

\section{CONCLUSIONS}

The present study reveals that the extracts from

FIGURE 3 - MS2 spectra in negative ion mode of compounds from leaves and stem bark extracts : stenophyllanin A (a), casuarinin (b), (-)-epicatechin (c) and (-)-epicatechin-3-O-glucoside (d).

leaves and stem bark of Anisophyllea laurina were better achieved using ethanol and methanol as extracting solvents of TPC, TFC, TMAC and TTC compared to ethyl acetate and water. However, the total tannin content in seed and leaves extracts were higher than pulp and stem bark extracts. These results have also shown that total 
phenolic, flavonoids, anthocyanins, tannin contents and antioxidant compounds from leaves and stem bark were significantly affected by the type of extraction solvent used. The findings in this study have demonstrated that the leaves and stem bark of $A$. laurina could primarily be a good source of mineral contents. Palmitic acid (C16:0), linolenic acid (C18:3n3), linoleic acid (C18:2n6) and oleic acid (C18:1n9) were the most abundant fatty acids in the leaves and stem bark extracts. Among the phenolic compounds identified from samples, Casuarinin isomer and Stenophyllanin A were abundant in leaves whereas stem bark was rich in several procyanidins. This work has quantified for the first time the phenolic compounds of a large number of leaves and stem bark of Anisophyllea laurina. It can therefore be concluded that the plant parts of A. laurina extracts maybe developed as a functional ingredient in nutraceuticals, and health-promoting phytochemicals.

\section{ACKNOWLEDGEMENTS}

The authors gratefully acknowledge the National Natural Science Foundation of China (31271812), the National High Technology Research and Development Program of China (863 Program 2012AA022105C for providing financial support for the study.

\section{REFERENCES}

ABBAS, Z.K.; SAGGU, S.; SAKERAN, M.I.; ZIDAN, N.; REHMAN, H.; ANSARI, A.A. Phytochemical, antioxidant and mineral composition of hydroalcoholic extract of chicory (Cichorium intybus L.) leaves. Saudi J. Biol. Sci., v.22, n.3, p.322-326, 2015.

ANITHA, T. Medicinal plants used in skin protection. Asian J. Pharm. Clin. Res., v.5, Suppl. 3, p.35-38, 2012.

ASSOCIATION OF ANALYTICAL COMMUNITIES. AOAC. Official methods of analysis of AOAC. $17^{\text {th }}$. ed. Gaithersburg, MD: Association of Analytical Communities, 2000. 2v.

BALDE, M.A.; TRAORE, M.S.; DIANE, S.; DIALLO, M.S.T.; TOUNKARA, T.M.; CAMARA, A.; BALDÉ, E.S.; BAH, F.; OUEDRAOGO, U.; DRAME, H. Ethnobotanical survey of medicinal plants traditionally used in low and middle guinea for the treatment of skin diseases. J. Plant. Sci., v.3, n.(1-2), p.32-39, 2015.
BARROS, L.; ALVES, C.T.; DUEÑAS, M.; SILVA, S.; OLIVEIRA, R.; CARVALHO, A.M.; HENRIQUES, M.; SANTOS-BUELGA, C.; FERREIRA, I.C.F.R. Characterization of phenolic compounds in wild medicinal flowers from Portugal by HPLC-DAD-ESI/MS and evaluation of antifungal properties. Ind. Crop. Prod., v.44, p.104-110, 2013a.

BARROS, L.; DUEÑAS, M.; ALVES, C.T.; SILVA, S.; HENRIQUES, M.; SANTOS-BUELGA, C.; FERREIRA, I.C.F.R. Antifungal activity and detailed chemical characterization of Cistus ladanifer phenolic extracts. Ind. Crop Prod., v.41, p.41-45, 2013 b.

CHEN, C.; RUI, X.; LU, Z.; LI, W.; DONG, M. Enhanced shelf-life of tofu by using bacteriocinogenic Weissella hellenica D1501 as bioprotective cultures. Food Control, v.46, p.203-209, 2014.

DAY, R.A.; UNDERWOOD, A.L. Quantitative analysis. $5^{\text {th }}$. ed. Englewood Cliffs, N.J: Prentice-Hall Publication, 1986. $189 \mathrm{p}$.

DIAS, M.I.; BARROS, L.; OLIVEIRA, M.B.P.P.; SANTOSBUELGA, C.; FERREIRA, I.C.F.R. Phenolic profile and antioxidant properties of commercial and wild Fragaria vesca L. roots: A comparison between hydromethanolic and aqueous extracts. Ind. Crop Prod., v.63, p.125-132, 2015.

EDWIGE, D.-A. Nutritional and microbiological characterization of pulp powder of locust bean (Parkia biglobosa Benth.) used as a supplement in infant feeding in Northern Benin. AJFS, v.6, n.9, p.232-238, 2012.

ERBAŞ, M.; CERTEL, M.; USLU, M.K. Some chemical properties of white lupin seeds (Lupinus albus L.). Food Chem., v.89, n.3, p.341-345, 2005.

FATTORE, E.; BOSETTI, C.; BRIGHENTI, F.; AGOSTONI, C.; FATTORE, G. Palm oil and blood lipid-related markers of cardiovascular disease: a systematic review and metaanalysis of dietary intervention trials. Am. J. Clin. Nutr., v.99, n.6, p.1331-1350, 2014.

GOUVEIA, S.; CASTILHO, P.C. Antioxidant potential of Artemisia argentea L'Hér alcoholic extract and its relation with the phenolic composition. Food Res. Int., v.44, n.6, p.1620-1631, 2011. 
HWANG, S.J.; YOON, W.B.; LEE, O.H.; CHA, S.J.; KIM, J.D. Radical-scavenging-linked antioxidant activities of extracts from black chokeberry and blueberry cultivated in Korea. Food Chem., v.146, p.71-77, 2014.

JARRETT, H.; COOKSY, K.; ELLIS, B.; ANDERSON, J. The separation of o-phthalaldehyde derivatives of amino acids by reversed phase chromatography on octylsilica columns. Anal. Biochem., v.153, n.1, p.189-198, 1986.

JUNCOSA, A.M. A historical and taxonomic synopsis of Rhizophoraceae and Anisophylleaceae. Ann. Missouri. Bot. Gard., v.75, n.4, p.1278-1295, 1988.

KARGBO, M.B.R.; ONIVOGUI, G.; SONG, Y. In vitro antidiabetic activity and phenolic compound profile of ethanol extracts of Anisophyllea laurina R. Br. ex Sabine leaves and stem bark. Eur. Acad. Res., v.2, n.12, p.16089-16106, 2015.

KHALLOUKI, F.; HAUBNER, R.; HULL, W.E.; ERBEN, G.; SPIEGELHALDER, B.; BARTSCH, H.; OWEN, R.W. Isolation, purification and identification of ellagic acid derivatives, catechins, and procyanidins from the root bark of Anisophyllea dichostyla R. Br. Food Chem. Toxicol., v.45, n.3, p.472-485, 2007.

KOREKAR, G.; STOBDAN, T.; SINGH, H.; CHAURASIA, O.P.; SINGH, S.B. Phenolic content and antioxidant capacity of various solvent extracts from seabuckthorn (Hippophae rhamnoides L.) fruit pulp, seeds, leaves and stem bark. Acta Aliment. Hung, v.40, n.4, p.449-458, 2011.

LEBBIE, A.R.; RAYMOND, G.P. Ethnobotanical value and conservation of sacred groves of the kpaa mende in sierra leone. Econ. Bot., v.49, n.3, p.297-308, 1995.

LU, M.; YUAN, B.; ZENG, M.; CHEN, J. Antioxidant capacity and major phenolic compounds of spices commonly consumed in China. Food Res. Int., v.44, n.2, p.530-536, 2011.

MENDEZ, L.; ROJAS, J.; IZAGUIRRE, C.; CONTRERAS, B.; GOMEZ, R. Jatropha curcas leaves analysis, reveals it as mineral source for low sodium diets. Food Chem., v.165, p.575-577, 2014.

NEUWINGER, H.D. African traditional medicine: a dictionary of plant use and applications. Stuttgart, Germany: Medpharm Scientific, 2000. p.589.
ONIVOGUI, G.; DIABY, M.; CHEN, X.; ZHANG, H.; KARGBO, M.R.; SONG, Y. Antibacterial and antifungal activities of various solvent extracts from the leaves and stem bark of Anisophyllea laurina R. Br ex Sabine used as traditional medicine in Guinea. J. Ethnopharmacol., v.168, p.287-290, 2015.

PARVATHI, A.; RAMYA, I.M.; REKHA, S. Evaluation of phytoconstituents in aqueous and organic extracts of aegle marmelos (1.) correa. and punica granatum 1. IJPCBS, v.3, n.4, p.1024-1031, 2013.

RAZALI, N.; MAT-JUNIT, S.; ABDUL-MUTHALIB, A.F.; SUBRAMANIAM, S.; ABDUL-AZIZ, A. Effects of various solvents on the extraction of antioxidant phenolics from the leaves, seeds, veins and skins of Tamarindus indica L. Food Chem., v.131, n.2, p.441-448, 2012.

SIMIRGIOTIS, M.J.; SILVA, M.; BECERRA, J.; SCHMEDAHIRSCHMANN, G. Direct characterisation of phenolic antioxidants in infusions from four Mapuche medicinal plants by liquid chromatography with diode array detection (HPLC-DAD) and electrospray ionisation tandem mass spectrometry (HPLC-ESI-MS). Food Chem., v.131, n.1, p.318-327, 2012.

SONG, Y.; XU, Q.; PARK, Y.; HOLLENBECK, A.; SCHATZKIN, A.; CHEN, H. Multivitamins, individual vitamin and mineral supplements, and risk of diabetes among older U.S. adults. Diabetes Care, v.34, n.1, p.108$114,2010$.

STANKOVIC, M.S.; NICIFOROVIC, N.; TOPUZOVIC, M.; SOLUJIC, S. Total phenolic content, flavonoid concentrations and antioxidant activity, of the whole plant and plant parts extracts fromteucrium montanuml. Var. Montanum, F.Supinum(L.) Reichenb. Biotechnol Biotec. Eq., v.25, n.1, p.2222-2227, 2011.

SUN, B.; RICHARDO-DA-SILVIA, J.M.; SPRANGER, I. Critical factors of vanillin assay for catechins and proanthocyanidins. J. Agric. Food Chem., v.46, n.10, p.4267-4274, 1998.

USENIK, V.; FABCIC, J.; STAMPAR, F. Sugars, organic acids, phenolic composition and antioxidant activity of sweet cherry (Prunus avium L.). Food Chem., v.107, n.1, p.185192, 2008. 
WORLD HEALTH ORGANIZATION. WHO. Protein and amino acid requirements in human nutrition. Geneva: WHO, 2007. p.150.

YOKOZAWA, T.; KIM, H.Y.; CHO, E.J.; CHOI, J.S.; CHUNG, H.Y. Antioxidant effects of Isorhamnetin3,7-Di-O-Dglucopyranoside isolated from mustard leaf (Brassica juncea) in rats with streptozotocin-induced diabetes. $J$. Agric. Food Chem., v.50, n.19, p.5490-5495, 2002.
ZHANG, L.B.; SIMMONS, M.P.; RENNER, S.S. A phylogeny of Anisophylleaceae based on six nuclear and plastid loci: ancient disjunctions and recent dispersal between South America, Africa, and Asia. Mol. Phylogenet. Evol., v.44, n.3, p.1057-1067, 2007.

Received for publication on $10^{\text {th }}$ March 2016 Accepted for publication on $19^{\text {th }}$ December 2016 